\title{
KUALITAS AUDIT: PENGARUH KARAKTERISTIK PERUSAHAAN DAN TATA KELOLA PERUSAHAAN
}

\author{
Cynthia Dewi* dan Anita* \\ *Jurusan Akuntansi, Fakultas Ekonomi \\ Universitas Internasional Batam \\ *E-mail: cynthiaa.dewi11@yahoo.com; anita.lec@uib.ac.id
}

\begin{abstract}
The purpose of this study is to quantify the effect of company's characteristics and corporate governance towards audit quality in companies listed in the Indonesia Stock Exchange (IDX). Independent board, board size, foreign ownership, ownership concentration, profitability as well as institutional ownership is used in this study. The amount of 618 companies listed on the Indonesia Stock Exchange during the period of 2013-2017 is used in this study. Purposive sampling method is used in the study. Financial statements of company that was published (www.idx.co.id) used as the sample of this study. The calibration of data which was obtained with binary logistic regression will be process using the program of SPSS version 25.0. This research shows that board size, foreign ownership and profitability proved to have a positive and significant relation on audit quality. This research also shows that institutional ownership does not have a significant relationship on audit quality while board independence has a negative relationship towards audit quality.
\end{abstract}

Keywords: audit quality, company characteristics, corporate governance.

\section{PENDAHULUAN}

Hasil kinerja yang dicapai oleh perusahaan dalam suatu periode dapat dilihat dari laporan keuangan perusahaan tersebut. Para investor maupun calon investor dalam membuat suatu keputusan sangat dipengaruhi oleh kualitas laporan keuangan perusahaan sehingga diperlukan adanya pihak eksternal yang berfungsi dalam menunjang kualitas laporan yang dihasilkan lewat kegiatan audit (Pouraghajan, Ali, Tabari, \& Haghparast, 2013). Laporan keuangan dapat dikatakan berguna bagi pihak pengambill keputusan adalah jika laporan tersebut merupakan laporan yang berkualitas atau yang memenuhi kriteria relevansi dan reliabilitas. Apabila laporan keuangan yang dihasilkan telah memenuhi kriteria dan telah diaudit, maka kepercayaan atas kebenaran laporan keuangan akan meningkat (Halim, 2015).

Audit didefinisikan sebagai sebuah pemeriksaan yang objektif dan merupakan proses penyelidikan atas penyertaan akun yang berkaitan dengan kas maupun setara kas yang juga mencakup pemeriksaan atas dokumen yang mendasarinya dan terkadang, aset fisik yang memungkinkan auditor membentuk pendapat mengenai benar atau tidaknya pernyataan yang telah disajikan (Okolo, 1989).

Menurut Okpanachi (2018), kualitas audit merupakan sebuah konstruksi multidimensi yang terbukti cukup sulit untuk diukur. Hingga saat ini, belum ada keseragaman definisi atas kualitas audit. Pernyataan tersebut didukung oleh Yuniarti (2011), yang memaparkan bahwa kualitas audit sukar diukur, abstrak dan hanya didapatkan oleh pengguna layanan audit. Definisi kualitas audit yang paling banyak digunakan adalah pengertian menurut Deangelo (1981), kualitas audit menguji probabilitas dimana seorang auditor melaporkan dan memastikan kesalahan material, pemalsuan dan 
pengecualian yang ia temukan dalam sistem akuntansi klien.

Tata kelola perusahaan memastikan semua pihak dalam perusahaan dari atasan sampai bawahan melaksanakan mekanisme dan tindakan yang dapat meningkatkan akuntanbilitas perusahaan (Ebere, 2015). Kurangnya kode tata kelola perusahaan akan menyebabkan keruntuhan banyak organisasi melalui penyalahgunaan kekuasaan, kecerobohan dalam menangani keuangan yang mengarah kepada ketidakmampuan dalam finansial, ketidakmampuan untuk mengikuti tata letak sistem pengendalian internal yang menyebabkan kekurangan pimpinan organisasi yang kredibel terutama dalam hal perekrutan tenaga kerja yang nantinya akan berpengaruh dalam pencapaian tujuan organisasi tersebut.

\section{Struktur kepemilikan juga} merupakan salah satu dorongan untuk mengawasi pelaporan keuangan dan melibatkan audit. Salah satu alasannya adalah karena laporan keuangan yang telah diaudit merupakan sumber daya penting bagi informasi tentang nilai perusahaan dan investor secara signifikan dalam menganalisis informasi akuntansi dan pembuatan keputusan keuangan tentang kualitas audit dan jenis laporan auditor. Struktur kepemilikan dan dewan direksi dianggap sebagai pengukuran yang efektif pada pertumbuhan ekonomi perusahaan. Beberapa komposisi struktur kepemilikan adalah seperti pemegang saham institusional dan pemegang saham utama yang dapat mempengaruhi keuangan perusahaan dan kebijakan strategisnya (Hoseinbeglou, Masrori, \& Asadzadeh, 2013).

$\begin{array}{ccc}\text { Manajemen didalam suatu } \\ \text { perusahaan akan dipengaruhi } & \text { oleh }\end{array}$ kepemilikan yang terkonsentrasi. Ketika pemegang saham yang memiliki saham dalam jumlah yang besar terutama ketika menjadi anggota dewan dan sahamnya melampaui dewan yang lain. Pemantauan yang dilakukan oleh pemegang saham yang memiliki saham dalam jumlah yang besar akan memberikan akses pribadi dan nilai informasi yang relevan (Helfin \& Shaw, 2000 dalam Zureigat, 2011).

Melalui latar belakang diatas dan penelitian terdahulu mengenai kualitas audit, maka peneliti akan melakukan penelitian atas perusahaan yang terdaftar di Bursa Efek Indonesia (BEI). Penelitian ini mengambil judul "Analisis Pengaruh Karakteristik Perusahaan dan Tata Kelola Perusahaan terhadap Kualitas Audit pada Perusahaan yang Terdaftar di Bursa Efek Indonesia (BEI)".

\section{KAJIAN LITERATUR DAN PENGEMBANGAN HIPOTESIS}

Peran audit merupakan suatu bentuk pengurangan atas kesenjangan informasi atas angka akuntansi serta untuk meminimalisir kerugian residual atas kesempatan manajerial dalam pelaporan laporan keuangan yang nantinya akan menjadi suatu jaminan bagi para investor yang mengandalkan laporan keuangan hasil audit tersebut (Adeniyi \& Mieseigha, 2013). Deis dan Giroux (1992), menyatakan bahwa dengan adanya pihak ketiga yang melakukan pemeriksaaan terhadap hasil kerja audit dapat menghasilkan kualitas audit yang lebih baik. Kualitas audit mengacu pada kemampuan pelaksanaan audit dalam mendeteksi kesalahan material dan penipuan yang mengarah kepada kesalahan penyajian didalam laporan keuangan (Akhalumeh et al., 2017). Konsep dari struktur kepemilikan dan kualitas audit saling berkaitan satu sama lain karena merupakan alat dalam tata kelola perusahaan yang mempengaruhi kualitas audit. Pengaruh kualitas audit oleh struktur kepemilikan sudah diperdebatkan secara teoritis dan empiris dalam literatur keuangan. Penelitian sebelumnya mendokumentasikan bahwa karena pemilik meratifikasi pemilihan auditor, sehingga auditor menganggap mereka sebagai klien dan melindungi kepentingan mereka. Ini dapat memberikan kesempatan kepada pemegang saham untuk memanipulasi 
laporan audit yang akan menurunkan tingkat kualitas audit (Odudu, Terzungwe, \& Joshua, 2018).

Penelitian yang dilakukan Boone, Khurana, dan Raman (2009), menyampaikan bahwa investor menganggap bahwa kualitas audit akan lebih tinggi jika diaudit oleh perusahaan audit Big four. Auditor Big four meliputi Ernst and Young, Klynveld Peat Marwick Goerdeler, Price Waterhouse Coopers dan Deloitte. Salah satu cara untuk mengukur kualitas audit secara tidak langsung yaitu dengan menggunakan ukuran audit yang merupakan variabel dummy, dimana ukuran audit tergantung audit perusahaan termasuk Big four atau non Big four (Adeniyi \& Mieseigha, 2013).

Penelitian tentang dampak karakteristik perusahaan atas kualitas audit di perusahaan yang terdaftar pada Bursa Efek Tehran diteliti oleh Pouraghajan et al. (2013), menggunakan kualitas audit sebagai variabel dependen. Kepemilikan institutional, ownership of natural persons serta kepemilikan manajerial sebagai variabel independent sedangkan ukuran perusahaan dan financial leverage adalah variabel kontrol. Velnampy et al. (2014) juga meneliti hubungan antara struktur kepemilikan pada kualitas audit. Kualitas audit selaku variabel dependen, dengan variabel independen yang terdiri dari board leadership structure, rapat komite audit, direktur non-eksekutif, dan direktur independen non-eksekutif.

Dewan direksi independen yaitu pihak yang tidak memiliki hubungan keluarga dengan mereka yang memegang saham atau kekuasaan atas perusahaan. Keputusan mereka cenderung lebih selaras dengan kepentingan pemegang saham. Mekamisme control yang terbaik dalam memantau dan mengawasi tindakan manajemen adalah dewan direksi. Teori agensi berfokus pada kepastian efektivitas proses pemantauan (Kasim et al., 2016).

Menurut Rahardja (2014), ukuran dewan direksi merupakan mekanisme tata kelola perusahaan yang mempunyai penting untuk menentukan kinerja perusahaan. Pemisahan peranan antara dewan direksi dan komisaris menjadikan dewan direksi memiliki wewenang dalam mengelola sumber daya perusahaan. Fama et al. (1983) mengemukakan bahwa dewan direksi merupakan mekanisme kontrol terbaik untuk memantau tindakan manajemen. Studi ini mengeksplorasi independensi dewan berdasarkan teori keagenan yaitu, bahwa ukuran dewan direksi yang besar cenderung memiliki kesulitan untuk berfungsi secara efektif, karena sejumlah besar administrator menciptakan konflik keagenan dan membuat lebih sulit untuk mencapai konsensus (Nekhili \& Cherif, 2009).

Profitabilitas yaitu kemampuan perusahaan memperoleh laba melalui total aset, modal sendiri dan penjualan. Profitabilitas mempunyai peranan yang sangat penting bagi perusahaan dan investor. Bagi sebuah perusahaan, profitabilitas adalah tujuan dan alasan mengapa sebuah perusahaan itu didirikan. Keuntungan tertinggi untuk perusahaan atas profitabilitas baik yaitu akan meningkatkan ketertarikan investor pada perusahaan (Rahardja, 2014). Perusahaan jika diaudit oleh KAP besar memiliki profitabilitas yang tinggi pula, ceteris paribus. Perusahan yang memiliki profitabilitas tinggi juga cenderung menunjuk auditor dengan skala yang lebih besar yang menunjukkan kualitas audit yang lebih tinggi (Anafiah et al., 2017). Profitabilitas dalam perusahaan menggambarkan keefektivitas yang dicapai oleh perusahaan sehingga bisa mengukur efisiensi kinerja serta dapat sebagai fungsi kontrol dan perencanaan didalam perusahaan (Anissa, 2004).

Konsentrasi

kepemilikan diindentifikasikan sebagai instrumen yang paling umum, yang digunakan sebagai alat pemantauan manajer yang cukup efisien (Kalezić, 2015). Liu dan Lai (2012) dalam Mahdavi et al. (2011), membuktikan bahwa perusahaan dengan dewan pengawas yang kecil dan tingkat 
konsentrasi kepemilikan yang tinggi cenderung memilih perusahaan audit berkualitas tinggi. Perusahaan yang besar dan perusahaan yang kepemilikannya $>50 \%$ juga cenderung melibatkan auditor KAP big 4 didalamnya (Niskanen et al., 2009).

Kepemilikan institusional ialah kepemilikan yang dipegang lembaga keuangan atau institusi lainnya. Yahyazadehfar et al. (2015), menyatakan kepemilikan institusional merupakan kelompok kepemilikan yang sangat memperhatikan kualitas informasi dan sangat mempengaruhi manajemen dalam menggunakan kualitas audit yang tinggi. Penelitian dari Pouraghajan et al. (2013), mengungkapkan hasil penelitiannya dimana kepemilikan institusional mempunyai dampak yang signifikan dan positif terhadap kualias audit. Adanya peningkatan kepemilikan institusional maka akan mempengaruhi kualitas audit. Investor institusi dalam menganalisa laporan keuangan biasanya lebih menuntut informasi yang berkualitas tinggi dan dapat dipercaya dan dikarenakan mereka mempunyai kuasa yang lebih tinggi dalam perusahaan sehingga cenderung akan menuntut pengurus perusahaan agar menggunakan jasa audit yang berkualitas tinggi.

Kepemilikan asing ialah segala macam investasi dari berasal dari investor yang berada di luar negara, baik badan ataupun perorangan yang bukan warga negara Indonesia (Pratama \& Muchamad, 2013). Kepemilikan asing berperan dalam memaksimalkan profit pemegang saham dan berfungsi sebagai institusi finansial dalam mensukseskan bisnis perusahaan (Shan, 2014). Kehadiran kepemilikan asing ditemukan mempengaruhi peningkatan kualitas audit. Adanya kehadiran kepemilikan asing maka semakin tinggi tuntutan atas kualitas pelaporan keuangan yang berkualitas tinggi dan terpercaya. Sehingga, semakin tinggi tingkat kepemilikan asing suatu entitas maka entitas tersebut cenderung terdorong untuk melakukan peningkatan transparansi atas laporan keuangan untuk meminimalisir keputusan oportunistik oleh manajemen atas kualitas audit (Sumantaningrum \& Kiswara, 2017).

Berdasarkan uraian dan kerangka model di atas maka hipotesis untuk penelitian ini adalah:

$\mathrm{H}_{1}$ : Dewan direksi independen berdampak signifikan positif pada kualitas audit.

$\mathrm{H}_{2}$ : Ukuran dewan direksi berdampak signifikan positif pada kualitas audit.

$\mathrm{H}_{3}$ : Konsentrasi kepemilikan berdampak signifikan positif pada kualitas audit.

$\mathrm{H}_{4}$ : Kepemilikan institusional berdampak signifikan negatif pada kualitas audit.

$\mathrm{H}_{5}$ : Kepemilikan asing berdampak signifikan positif pada kualitas audit.

$\mathrm{H}_{6}$ : Profitabilitas berdampak signifikan negatif pada kualitas audit.

\section{METODOLOGI PENELITIAN}

Penelitian ini adalah perkembangan dari model penelitian terdahulu. Berdasarkan sifat data yang dikumpulkan penelitian ini bersifat kuantitatif yang berarti metode penelitian dilakukan berdasarkan pada filsafat positivisme untuk meneliti populasi atau sampel tertentu. Pengumpulan data memanfaatkan analisis data bersifat statistik yang bertujuan menguji hipotesis yang sudah ditetapkan (Sugiyono, 2017).

Penelitian ini merupakan penelitian kausal-komparatif yang berfokus pada membandingkan variabel bebas kelompok subjek tertentu yang berpengaruh berbeda dari variabel bebas. Pengaruh variabel bebas pada variabel terikat adalah pengaruh telah berlangsung sebelum penelitian terjadi (Husna \& Suryana, 2017).

Perusahaan yang terdaftar di Bursa Efek Indonesia (BEI) pada tahun 2013-2017 merupakan objek dari penelitian ini. Pengambilan sampel menggunakan metode purposive sampling, yang hanya dapat dilakukan oleh peneliti yang tau dengan jelas karakteristik populasi, atau yang telah mengenal betul populasi yang akan diteliti. Penentuan sampel berdasarkan tujuan 
tertentu yang telah ditetapkan (Rinaldi \& Mujianto, 2017).

Sampel penelitian yang dipilih harus memenuhi kriteria: 1) perusahaan terdaftar di BEI setelah tahun 2013; 2) perusahaan tidak termasuk perusahaan institusi keuangan, meliputi perusahaan sekuritas, perbankan, finansial dan asuransi. Perusahaan institusi keuangan dikeluarkan dari sampel penelitian ini karena karakteristik perusahaan tersebut berbeda dari perusahaan yang lainnya dalam hal pelaporan keuangan mengenai penilaian likuiditas dan profitabilitas. Perhitungan pajak serta aturan akuntansinya juga berbeda. (Soliman \& Elsalam, 2012); 3) perusahaan menyediakan laporan keuangan yang lengkap dari tahun 2013-2017 dan data penelitian meliputi auditor, jumlah dewan komisaris, direksi, direksi independen, kepemilikan asing, kepemilikan institusional, konsentrasi kepemilikan, laba per saham, total aset, total kewajiban serta total saham.

Variabel dependen dari penelitian ini adalah kualitas audit yang memiliki variabel independen terdiri dari dewan direksi dan direksi independen, profitabilitas, konsentrasi kepemilikan, kepemilikan institusional, kepemilikan asing dan variabel kontrol meliputi ukuran perusahaan dan leverage.

\section{Kualitas Audit}

Penelitian ini menggunakan kualitas audit sebagai variabel dependen dan merupakan variabel dummy, yang diukur dengan 0 jika tidak memenuhi kriteria, 1 jika memenuhi kriteria yang ditetapkan. Pengukuran dependen dalam penelitian ini menggunakan cara jika perusahaan yang diteliti menggunakan jasa big four sebagai auditornya maka 1, dan jika tidak maka 0 (Akhalumeh et al., 2017)

The big four di Indonesia terdiri dari: 1) KAP Osman Bing Satrio dan Eny berafiliasi dengan Deloitte Touche Tohmatsu (Deloitte Touche Tohmatsu, 2019); 2) KAP Purwantono, Sarwoko, dan Sandjaja berafiliasi dengan Ernst and
Young (Ernst \& Young, 2019); 3) KAP Tanudiredja, Wibisana \& Rekan berafiliasi dengan Price Waterhouse Coopers (Price Waterhouse Coopers, 2019); 4) KAP Sidharta dan Widjaja berafiliasi dengan Klynveld Peat Marwick Goerdeler (Klynveld Peat Marwick Goerdeler, 2019).

\section{Dewan Direksi Independen}

Dewan direksi independen mempunyai peran yang penting jika terjadi masalah antara pemilik instansi dan manajer berdasarkan permasalahan agensi. Dewan direksi independen dalam penelitian ini dinotasikan sebagai BDIN (Akhalumeh et al., 2017).

$$
\text { BDIN }=\frac{\begin{array}{c}
\text { Persentase jumlah anggota } \\
\text { dewan direksi independen }
\end{array}}{\text { Direksi + Komisaris }}
$$

\section{Ukuran Dewan Direksi}

Ukuran dewan direksi dinotasikan dengan BDSZ (Akhalumeh et al., 2017). Ukuran dewan direksi diukur dengan jumlah dewan direksi didalam suatu perusahaan.

BDSZ = Jumlah anggota dewan

\section{Profitabilitas}

Profitabilitas dalam penelitian ini dinotasikan dengan FPR (Akhalumeh et al., 2017). Profitabilitas disini diukur dengan laba per lembar saham.

FPR = Laba per lembar saham

\section{Konsentrasi Kepemilikan}

Konsentrasi kepemilikan dinotasikan sebagai OC (Khasharmeh \& Joseph, 2017). Konsentrasi kepemilikan diukur dengan ukuran persentase saham yang dimiliki investor dengan kepemilikan lebih dari 5\% dari total saham perusahaan.

OC $=\begin{aligned} & \text { Persentase saham milik investor } \\ & \text { dengan kepemilikan }>5 \%\end{aligned}$ 


\section{Kepemilikan Institusional}

Kepemilikan institusional dalam penilitian ini dinotasikan sebagai IO (Khasharmeh \& Joseph, 2017). Pengukuran kepemilikan institusional didalam penelitian ini diukur dengan persentase dari total saham yang dimiliki oleh institusi investor besar seperti bank, perusahaan asuransi, perusahaan investasi.

IO $=\begin{aligned} & \text { Persentase saham milik institusi } \\ & \text { investor }\end{aligned}$

\section{Kepemilikan Asing}

Kepemilikan asing dalam penilitian ini dinotasikan sebagai FO (Khasharmeh \& Joseph, 2017). Pengukuran kepemilikan asing didalam penelitian ini diukur dengan persentase dari total saham yang dimiliki oleh investor asing.

FO $=\begin{aligned} & \text { Persentase saham milik } \\ & \text { investor asing }\end{aligned}$

\section{Leverage}

Leverage yang dinotasikan dengan LE, merupakan rasio pengukur kemampuan perusahaan memenuhi kewajiban jangka panjangnya. Leverage diukur dengan total kewajiban dibagi dengan total aset (Khasharmeh \& Joseph, 2017).

$$
\text { LE }=\frac{\text { Total Kewajiban }}{\text { Total Aset }}
$$

\section{Ukuran Perusahaan}

Ukuran perusahaan dinotasikan dengan CS, dalam penelitian ini diukur dengan logaritma total aset (Khasharmeh \& Joseph, 2017).

CS = Logaritma dari total aset

Penelitian ini memanfaatkan data sekunder, peneliti tidak secara langsung mengumpulkan data melainkan dari berbagai dokumen cetak ataupun elektronik (Husna \& Suryana, 2017). Teknik dokumentasi digunakan dalam penelitian ini dengan langsung melihat fail yang sudah tersedia. Data diperoleh melalui laporan audit perusahaan melalu situs perusahaan yang terdaftar di BEI yaitu www.idx.co.id merupakan media sarana informasi dalam memperoleh laporan yang telah di audit.

Statistik deskriptif merupakan statistik yang bertugas menganalisa angka sehingga dapat menghasilkan gambaran yang ringkas dan jelas tentang sebuah keadaan untuk dapat menarik makna tertentu (Rinaldi \& Mujianto, 2017). Standar deviasi dinyatakan bervariasi besar apabila suatu data berstandar deviasi > $14,5 \%$ dari nilai rata-rata (Santoso,2012).

Menurut Santoso (2012), definisi outlier yaitu peninjauan yang menyimpang jauh dari rata-rata, yang terlihat jelas berbeda dari data yang lain. Outlier akan menyebabkan data tidak terdistribusi normal. Cara pengujiannya yaitu dengan menggunakan nilai z-score. Uji outlier ditentukan berdasarkan jumlah sampel, jika jumlah sampel $<80$, maka pengamatan $\mathrm{z}$ score diantara 2.5 atau -2.5 adalah outlier. Tetapi jika jumlah sampel > 80, maka pengamatan $\mathrm{z}$ score diantara 3 atau -3 adalah outlier (Hair et al., (2010).

Uji multikolinearitas bertujuan menguji korelasi antar variabel independen. Penelitian yang menggunakan analisis binary logistic harus melakukan uji multikolinearitas. Seandainya ditemukannya korelasi maka masalah tersebut disebut dengan multikolinearitas. Model regresi yang baik seharusnya tidak terjadi korelasi diantara variabel independen atau dengan kata lain tidak terjadi multikolinearitas

Nilai VIF (Variance Inflation Factor) dan Tolerance dapat digunakan untuk mengetahui ada tidaknya korelasi dalam model regresi (Ghozali, 2006). Jika nilai toleransi < 0.1 dan nilai VIF > 10, maka model regresi terjadi multikolinearitas. Sedangkan jika nilai toleransi $>0.1$ dan nilai VIF $<10$, maka model regresi tidak terjadi multikolinearitas. 
Uji hipotesis bertujuan mengetahui pengaruh variabel independen pada dependen. Uji ini menggunakan metode regresi binary logistic karena skala pengukuran variabel dependen adalah skala nominal meliputi dua kategori. Pengujian regresi binary logistic terdiri dari uji Hosmer and Lemeshow's Goodness of Fit Test, uji Wald dan uji Nagelkerke R Square (Ghozali, 2006). Uji Hosmer and Lemeshow bertujuan untuk mengetahui apakah data empiris cocok dengan model. Ketepatan dan kecukupan data pada model regresi logistik dapat dilihat dari hasil uji ini. Nila Sig pada table Hosmer and Lemeshow diambil sebagai kriteria. Model dinyatakan layak apabila nilai Sig. > 0,05 begitu juga sebaliknya, jika nilai Sig. < 0,05, maka model dinyatakan tidak sesuai dengan data sampel (Ghozali, 2006).

Uji Wald bertujuan untuk mengetahui signifikansi masing-masing variabel independen beserta kontrol atas variabel dependen. Tabel Variables in the Equation digunakan sebagai kriteria pengukuran dimana jika nilai Sig $<0,05$, maka variabel tersebut berdampak signifikan atas variabel dependen. Sebaliknya, jika nilai Sig. > 0,05, maka variabel berdampak tidak signifikan dengan variabel dependen (Ghozali, 2006).
Uji Nagelkerke R Square dalam model regresi logistik berfungsi sama dengan Adjusted R Square dalam model regresi linier berganda, yaitu untuk menjelaskan seberapa besar variabel dependen dalam model regresi dijelaskan oleh variabel independe. Hasil uji ini mengukur seberapa besar variabel dependen dapat dijelaskan oleh variabel independen (Ghozali, 2006).

\section{HASIL PENELITIAN}

Penelitian ini menggunakan data sekunder. Objek penelitian ini yaitu laporan keuangan audit perusahaan terdaftar di BEI tahun 2013-2017. Data diproses menggunakan program SPSS versi 25.0.

Berdasarkan Tabel 1, perusahaan yang terdaftar di BEI sampai tahun 2017 terdapat 618 perusahaan. Jumlah perusahaan yang tidak memenuhi kriteria sebanyak 227 perusahaan, sehingga jumlah sampel sebanyak 391 perusahaan. Jumlah data penelitian adalah 1.955 data dan outlier sebanyak 915 data, sehingga jumlah data akhir yang digunakan dalam penelitian menjadi 1040 data. Sedangkan Tabel 2 akan menunjukkan hasil uji statistik deskriptif dalam penelitian ini.

\section{Tabel 1}

Daftar Jumlah Perusahaan yang Dijadikan Sampel

\begin{tabular}{lr}
\hline \multicolumn{1}{c}{ Keterangan } & Jumlah \\
\hline Perusahaan terdaftar di BEI & 618 perusahaan \\
Perusahaan terdaftar setelah 2013 & (131 perusahaan) \\
Perusahaan institusi keuangan (finansial, perbankan, sekuritas, & (76 perusahaan) \\
asuransi) & \\
Perusahaan yang tidak lengkap laporan keuangannya & (20 perusahaan) \\
Perusahaan yang dijadikan sampel & 391 perusahaan \\
Tahun & 5 tahun \\
Total data perusahaan & 1.955 data \\
Total outlier & (915) data \\
Total data bebas outlier & 1040 data \\
\hline
\end{tabular}

Sumber: Data penelitian diolah (2018) 
Tabel 2

Hasil Uji Statistik Deskriptif Variabel Penelitian

\begin{tabular}{lcccc}
\hline \multirow{2}{*}{ Variabel } & \multicolumn{4}{c}{ Statistika Deskriptif } \\
\cline { 2 - 5 } BDIN & Minimum & Maksimum & Rata-Rata & Std. Deviasi \\
BDSZ & 0,00000 & 0,50000 & 0,17480 & 0,22222 \\
FPR & 2,00000 & 9,00000 & 4,45580 & 1,59944 \\
OC & $-143,00000$ & 230,37000 & 32,10890 & 59,44087 \\
FO & 0,21000 & 0,99000 & 0,70930 & 0,16806 \\
IO & 0,00000 & 0,99000 & 0,23560 & 0,28666 \\
CS (dlm milyaran) & 0,10000 & 0,99000 & 0,66490 & 0,19948 \\
LEV & 10,32000 & 13,80000 & 12,24260 & 0,63979 \\
\hline
\end{tabular}

Sumber: Data penelitian diolah (2018)

Uji multikolinieritas dilakukan untuk melihat apakah antar variabel terdapat korelasi. Uji multikolinearitas dilakukan pada variabel selain vaariabel dependen, yaitu variabel independen dewan direksi independen, ukuran dewan direksi, profitabilitas, konsentrasi kepemilikan, kepemilikan institusional, kepemilikan asing, ukuran perusahaan dan leverage.

Berdasarkan hasil uji multikolinearitas pada Tabel 3 bahwa nilai VIF untuk semua variabel menunjukkan angka VIF $<10$ kurang dari 10 dan nilai tolerance yang lebih dengan nilai tolerance $>0,1$ yang berarti variabel diuji tidak terjadi multikolinearitas atau hubungan antar variabel.

Berdasarkan hasil uji Hosmer and Lemeshow pada table 4 dapat disimpulkan bahwa variabel independen mempengaruhi variabel dependen secara simultan. Nilai signifikansi harus $>0.05$ sehingga model regresi dapat digunakan untuk mengukur kualitas audit.

\section{Tabel 3}

Hasil Uji Multikolinearitas

\begin{tabular}{|c|c|c|c|}
\hline \multirow{2}{*}{ Variabel } & \multicolumn{2}{|c|}{ Collinearity Statistics } & \multirow{2}{*}{ Kesimpulan } \\
\hline & Tolerance & VIF & \\
\hline BDIN & 0,957 & 1,056 & Tidak Terjadi Multikolinearitas \\
\hline BDSZ & 1,448 & 1,448 & Tidak Terjadi Multikolinearitas \\
\hline FPR & 0,952 & 1,051 & Tidak Terjadi Multikolinearitas \\
\hline $\mathrm{OC}$ & 0,356 & 2,811 & Tidak Terjadi Multikolinearitas \\
\hline $\mathrm{FO}$ & 0,896 & 1,151 & Tidak Terjadi Multikolinearitas \\
\hline IO & 0,369 & 2,712 & Tidak Terjadi Multikolinearitas \\
\hline CS (dlm milyaran) & 0,600 & 1,668 & Tidak Terjadi Multikolinearitas \\
\hline LEV & 0,872 & 1,147 & Tidak Terjadi Multikolinearitas \\
\hline
\end{tabular}

Sumber: Data sekunder diolah (2018)

Tabel 4

Hasil Uji Hosmer and Lemeshow

\begin{tabular}{cccc}
\hline Variabel Dependen & Df & Sig. & Kesimpulan \\
\hline AUD & 8 & 0,074 & Model Sesuai \\
\hline
\end{tabular}

Sumber: Data sekunder diolah (2018) 
Hasil penelitian Tabel 5 menunjukkan bahwa dewan direksi independen mempunyai dampak signifikan negatif pada kualitas audit. Hasil ini sesuai dengan hipotesis yang diungkapkan oleh (Mgbame et al., 2012), Mgbame dan Osazuwa (2012), Soliman dan Elsalam (2013), (Adeniyi \& Mieseigha, 2013), dan Gacar (2016) tetapi tidak konsisten dengan penelitian Salleh dan Manson (2006) dalam Abdullah et al. (2006), Lin (2010), Akhalumeh et al. (2017), Bett (2017), dan Khasharmeh dan Joseph (2017).

Hasil penelitian Tabel 5 menyatakan ukuran dewan direksi mempunyai hubungan positif signifikan terhadap kualitas audit. Hubungan tersebut menyatakan bahwa semakin tinggi variabel ukuran dewan direksi maka semakin bagus kualitas audit yang dimiliki perusahaan. Adanya penambahan atas jumlah ukuran dewan akan memunculkan dorongan untuk memilih audit yang berkualitas tinggi agar dapat meningkatkan tingkat pengawasan, karena penambahan anggota dewan akan meningkatkan persentase terjadinya konflik (Pizetta \& Dacosta, 2013). Hasil ini konsisten dengan penelitian terdahulu Geudhami et al. (2007), Aksu et al. (2007), Zureigat (2011), Karim et al. (2012), Shan (2014), Talebnia et al. (2017); Dwekat, Mardawi, dan Abdeljawad (2018), Asiriuwa et al. (2018), serta Wang dan Zhu (2018) tetapi inkonsisten dengan penelitian Mgbame et al. (2012), Siregar et al. (2012), Sakka dan Jarboui (2015), dan Ibrahim dan Jehu (2018).

Tabel 5

Hasil Uji Wald

\begin{tabular}{lccccl}
\hline \multicolumn{1}{c}{ Variabel } & B & Wald & Sig. & Kesimpulan & Hipotesis \\
\hline Constant $)$ & $-4,145$ & 84,619 & 0,000 & & \\
BDIN & $-0,476$ & 6,299 & 0,012 & Signifikan negatif & Tidak dapat dibuktikan \\
BDSZ & 0,144 & 7,329 & 0,007 & Signifikan positif & Dapat dibuktikan \\
FPR & 0,005 & 19,640 & 0,000 & Signifikan positif & Tidak dapat dibuktikan \\
OC & 1,687 & 0,813 & 0,038 & Signifikan positif & Dapat dibuktikan \\
IO & 0,412 & 0,361 & 0,548 & Tidak signifikan & Tidak dapat dibuktikan \\
FO & 0,633 & 0,280 & 0,024 & Signifikan positif & Dapat dibuktikan \\
CS & 1,392 & 68,537 & 0,000 & Signifikan positif & \\
LEVERAGE & $-2,502$ & 0,273 & 0,000 & Signifikan negatif & \\
\hline
\end{tabular}

Sumber: Data sekunder diolah (2018)

Hasil penelitian Tabel 5 menunjukkan profitabilitas memiliki nilai signifikansi sebesar $0,000<0,050$. Profitabilitas berpengaruh secara signifikan positif terhadap kualitas audit karena memiliki signifikansi kurang dari alpha. Menurut Lin dan Liu (2009), meningkatnya profitabilitas perusahaan akan berdampak pada kualitas audit. Tingginya profitabilitas menyebabkan perusahaan cenderung lebih memilih auditor yang berkualitas agar pandangan pasar atas kinerja perusahaannya akan meningkat. Hasil ini konsisten terhadap penelitian oleh Mgbame et al. (2012); 
Gana dan Krichen (2013); Adeniyi dan Mieseigha (2013); Anafiah et al. (2017) tetap tidak oleh Elshafie dan Nyadroh (2014).

$\begin{array}{lll}\text { Hasil penelitian } & \text { Tabel } 5 \\ \text { mengindikasikan bahwa } & \text { konsentrasi }\end{array}$ kepemilikan mempunyai hubungan yang positif dan signifikan terhadap kualitas audit. Peningkatan konsentrasi kepemilikan akan mempengaruhi kualitas audit. Hal ini dikarenakan adanya faktor pemantauan yang dilakukan oleh pihak pemengang saham mempengaruhi pemilihan auditor (Helfin \& Shaw, 2000). Hasil ini sesuai dengan hipotesis dan konsisten dengan penelitian terdahulu oleh Abdullah et al. (2006); Karaibrahimoglu (2013); Darabi dan Moghadam (2013); Ebere (2015); dan Dwekat et al. (2018). Palmrose (1988), Lukas (2009), Pouraghajan, Tabari, dan Haghparast (2013), membuktikan adanya hubungan signifikan negatif.

Hasil penelitian Tabel 5 menunjukkan kepemilikan institusional tidak berpengaruh signifikan terhadap kualitas audit walaupun mereka memiliki hubungan yang positif. Hasil menunjukkan nilai signifikansi $0,548>0,05$. Investor dari pihak institusi cenderung akan mendorong perusahaan untuk meningkatkan kualitas auditnya supaya investor bersedia untuk investasi (Velury et al., 2003). Hal ini konsisten terhadap hasil penelitian oleh Abdullah et al. (2006);
Soliman dan Elsalam (2013); tetapi inkonsisten terhadap hasil penelitian dari (Almutairi, 2013).

Hasil penelitian Tabel 5 menunjukkan kepemilikan asing memiliki nilai signifikansi $0,024<0,05$ sehingga kepemilikan asing berdampak signifikan positif terhadap kualitas audit karena memiliki signifikansi kurang dari alpha. Tingginya kepemilikan asing akan menyebabkan pengontrolan dan pengawasan pada aktivitas audit akan meningkat sehingga juga akan menyebabkan meningkatnya kualitas laporan audit. Kepemilikan asing dapat menyebabkan konflik dengan pihak manajemen atas kepentingan mereka (Niemi, 2005). Hal ini didukung oleh penelitian Aksu et al. (2007), Geudhami et al. (2007), Zureigat (2011), Karim et al. (2013), Shan (2014), serta Alzeaideen dan Al-rawash (2018). Tetapi tidak konsisten dengan hipotesis Guedhami et al. (2009).

Dari hasil uji Nagelkerke $R$ Square pada Tabel 6, dapat dilihat bahwa koefisiensi determinasi menghasilkan nilai sebesar 0,246 yang artinya pemilihan KAP sebesar $24,60 \%$ dijelaskan oleh variabel dewan direksi independen, ukuran dewan direksi, profitabilitas, konsentrasi kepemilikan, kepemilikan institusional dan asing, ukuran perusahaan serta dengan leverage. Sisa $75,4 \%$ oleh faktor lain yang tidak ada dalam model.

Tabel 6

Hasil Uji Nagelkerke R Square $\left(R^{2}\right)$

\begin{tabular}{cc}
\hline Variabel Dependen & Nagelkerke R Square \\
\hline Kualitas Audit & 0,246
\end{tabular}

Sumber: Data sekunder diolah (2018)

\section{KESIMPULAN}

Penelitian ini bertujuan menelaah faktor karakteristik perusahaan dan tata kelola perusahaan terhadap kualitas audit. Variabel independen, yaitu dewan direksi independen, kepemilikan institusional dan asing, ukuran dewan direksi, profitabilitas, konsentrasi kepemilikan, ukuran perusahaan serta dengan leverage sebagai faktor yang mempengaruhi kualitas audit. Berdasarkan hasil dan pembahasan pada bab sebelumnya, maka dapat disimpulkan bahwa variabel ukuran dewan direksi, profitabilitas, konsentrasi kepemilikan dan kepemilikan asing berpengaruh positif signifikan terhadap kualitas audit. Variabel 
kepemilikan institusional memiliki pengaruh tidak signifikan terhadap kualitas audit dan variable dewan direksi independen mempunyai pengaruh signifikan negatif terhadap kualitas audit.

Adapun keterbatasan yang dihadapi oleh peneliti: 1) sejumlah perusahaan di BEI mempunyai data laporan tahunan yang tidak lengkap lima tahun dari tahun 20132017 sehingga jumlah sampel berkurang; 2) hasil uji Nagelkerke R Square rendah yaitu sebesar 24,60\%, menandakan $75,40 \%$ variabel dependen dipengaruhi oleh variabel lain yang tidak dalam penelitian.

Adapun rekomendasi yang bertujuan untuk membantu pada penelitian selanjutnya, antara lain: 1) perluas sampel, misalnya dengan nambahkan tahun pengamatan; 2) menambahkan perbandingan agar dapat lebih jelas mengetahui perbedaan misalnya Amerika dengan Indonesia; 3) penelitian berikut diharapkan dapat menambahkan faktorfaktor lain yang diperkirakan juga mempunyai pengaruh atas kualitas audit seperti reputasi perusahaan (Aronmwan \& Ashafoke, 2016); pengalaman auditor (Yasin \& Nelson, 2013); tenur audit (Siregar, Amarullah, Wibowo, \& Anggraita, 2012); keterlambatan audit dan audit fees (Carey, Simnett, Carey, \& Simnett, 2013).

\section{DAFTAR PUSTAKA}

Abbott, L. J., Parker, S., Peters, G. F., \& Raghunandan, K. (2003). The association between audit committee characteristics and audit fees. Auditing, 22(2), 17-32.

Abedalqader Al-Thuneibat, A., Tawfiq Ibrahim Al Issa, R., \& Ata Baker, R. A. (2011). Do audit tenure and firm size contribute to audit quality? Managerial Auditing Journal, 26(4), 317-334.

Abid, A., Shaique, M., \& Anwar ul Haq, M. (2018). Do Big Four Auditors Always Provide Higher Audit Quality? Evidence from Pakistan.
International Journal of Financial Studies, 6(2), 58.

Abusbaiha, A. M. (2007). The Relation of Corporate Governance to Audit Quality: Case Study on Non Financial Companies Al. 2nd Conference in Business, Accountinng, and Management, 2(1992), 274-281.

Adeniyi, S. I., \& Mieseigha, E. G. (2013). Audit Tenure: an Assessment of its Effects on Audit Quality in Nigeria. International Journal of Academic Research in Accounting Finance and Management Sciences, 3(3), 275-283. Adeyemi, S. B., \& Fagbemi, T. O. (2010). Audit quality, corporate governance and firm characteristics in Nigeria. International Journal of Business and Management, 5(5), 169-179.

Akhalumeh, P., Agweda, F., \& Ogunkuade, Z. (2017). Corporate characteristics and audit quality: evidence from quoted firms in Nigeria. Journal of Scientific Research and Studies, 4(3), 59-66.

Almomani, M. A. (2015). The Impact of Audit Quality Features on Enhancing Earnings Quality: The Evidence of Listed Manufacturing Firms at Amman Stock Exchange, 7(2), 255280.

Almutairi, A. R. (2013). The impact of institutional ownership and corporate debt on audit quality.

Alqadasi, A., \& Abidin, S. (2017). The effectiveness of internal corporate governance and audit quality: the role of ownership concentration Malaysian evidence.

Alshammari, S. (2014). C Orporate G Overnance and D Irectors ' D Uties C Orporate G Overnance and $\mathrm{D}$ Irectors' D Uties.

Alzeaideen, K. A., \& Al-rawash, S. Z. (2018). The Effect of Ownership Structure and Corporate Debt on Audit Quality : Evidence from Jordan, 8(3), 51-58. 
Aronmwan, E., \& Ashafoke, T. O. (2016). Audit Firm Reputation and Audit Quality, (January 2013).

Asiriuwa, O., Aronmwan, E., Uwuigbe, U., State, O., \& Uwuigbe, O. R. (2018). Audit committee attributes and audit quality: A benchmark analysis, (May), 37-48.

Barua, A., Rama, D. V., \& Sharma, V. (2010). Audit committee characteristics and investment in internal auditing. Journal of Accounting and Public Policy, 29(5), 503-513.

Beasley, M., \& Petroni, K. (1998). Board Independence and Audit Firm Type. Brigham Young University, (October).

Beisland, L. A., Mersland, R., \& Øystein, R. (2013). Audit Quality and Corporate Governance: Evidence from the Microfinance Industry. Centre Emile Berheim, 32(0), 0-45.

Bett, T. C. (2017). EFFECTS OF CORPORATE GOVERNANCE ON AUDIT QUALITY OF PUBLIC FINANCIAL INSTITUTIONS IN KENYA $1 *$. International Journa of Social, III(Viii).

Boone, J., Khurana, I., \& Raman, K. (2009). Is Audit Quality Different for Big 4 and Mid-tier Auditors? Working Paper.

Carcello, J. V, Hermanson, D. R., Neal, T. L., \& Riley JR, R. A. (2002). Board Characteristics and Audit Fees. Contemporary Accounting Research, 19(3), 365-384.

Carey, P., Simnett, R., Carey, P., \& Simnett, R. (2013). No Title, 81(3), 653-676.

Chandren, S. A. P. (2018). Ownership structure and audit quality, 22(5), 2226.

Corbella, S., Florio, C., Gotti, G., \& Mastrolia, S. A. (2015). Audit firm rotation, audit fees and audit quality: The experience of Italian public companies. Journal of International
Accounting, Auditing and Taxation, 25, 46-66.

Deangelo, L. E. (1981). AUDITOR SIZE AND AUDIT QUALITY Linda Elizabeth DeANGELO*, 3(July), 183-199.

DeAngelo, L. E. (1981). Auditor size and audit quality. Journal of Accounting and Economics, 3(3), 183-199.

Deis, D. R., \& Giroux, G. A. (1992). Determinants of Audit Quality in the Public Sector. The Accounting Review, 67(3), 462-479.

Dwekat, A., Mardawi, Z., Abdeljawad, I., \& others. (2018). Corporate Governance and Auditor Quality Choice: Evidence from Palestinian Corporations. International Journal of Economics and Financial Issues, 8(2), 47-53.

Ebere, G. (2015). Corporate Governance and Audit Quality in Nigeria: Evidence From the Banking Industry. European Journal of Accounting, Auditing and Finance Research, 5(18), 18-39.

Elshafie, E., \& Nyadroh, E. (2014). Are Discretionary Accruals a Good Measure of Audit Quality? Journal of Management, 15(7), 43-60.

Enofe, A. O., Okunega, C. N., \& Ediae, O. O. (2013). Audit Quality and Auditors Independence in Nigeria: An Empirical Evaluation. Research Journal of Finance and Accounting, 4(11), 2222-2847.

Fama, E. F., Jensen, M. C., Law, J., \& Conference, P. P. a. (1983). Separation of Ownership and Control SEPARATION OF OWNERSHIP A N D CONTROL *. Control, 26(2), 301-325.

Gacar, A. (2016). Relationship Between Audit Quality and Corporate Governance: An Empirical Research in Borsa Istanbul. IOSR Journal of Business and Management (IOSRJBM), 18(11), 84-88.

Gana, M. R., \& Krichen, A. L. (2013). Board Characteristics and External 
Audit Quality: Complementary or Substitute Mechanisms? The Belgium Case Author's details. International Journal of Management Sciences and Business Research Azhaar Lajmi Krichen. Azhaar_lajmi@yahoo.Fr.Tunisie International Journal of Management Sciences and Business Research, 2(3), 2226-8235

Guedhami, O., Pittman, J. A., \& Saffar, W. (2009). Auditor choice in privatized firms Empirical evidence on the role of state and foreign owners. 2Journal of Accounting and Economics, 48(December 2007), 151-171.

Halim, A. (2015). Auditing: Dasar-Dasar Audit Laporan Keuangan (5th ed.). Yogyakarta: Unit Penerbit dan percetakan STIM YKPN.

Hassan, K., Khaldoon, A., \& Zhang, jin ping. (2015). Is audit quality Implied by Accruals Quality associated with Audit fees and Auditor Tenure? Evidence from China Kikhia.

Hay, D., \& Davis, D. (2004). The voluntary choice of an auditor of any level of quality. Department of Accounting and Finance, 23(2), 3753.

Ho Wai Kee, Yu Hock, and K. C. K. (2017). Corporate Governance and audit Quality. Malaysian Accounting Review, 6(1), 65-83.

Homayoun, S., \& Hakimzadeh, M. (2017). Audit Fee and Audit Quality: An Empirical Analysis in Family Firms. International Journal of Economics and Financial Issues, 7(2), 469-476.

Hoseinbeglou, S., Masrori, R., \& Asadzadeh, A. (2013). The Effect of Corporate Governance Mechanisms on Audit Quality. J. Basic. Appl. Sci. Res, 3(1), 891-897.

Husna, As., \& Suryana, B. (2017). metodologi penelitian dan statistik.

Ibn, S., \& Bala, H. (2015a). OWNERSHIP STRUCTURE AND AUDIT QUALITY. Journal of Social and Management Science, 2 no 3(1).
Ibn, S., \& Bala, H. (2015b). Ownership Structure and Audit Quality of Nigerian Deposit Money Ownership Structure and Audit Quality of Nigerian Deposit, (January 2017).

Ibrahim, M. A., \& Jehu, P. (2018). The Effect of Board Composition on The Informativeness of Financial Reporting Quality: Empirical Evidence from Nigeria, 20(3), 54-60.

Ibrahim, M., \& Ali, I. (2018). Impact of Audit Fees on Audit Quality of Conglomerates Companies in Nigeria, 5(1), 1-8.

Imanzadeh, P., \& Lalepour, M. (2013). The effect of corporate governance mechanisms on auditing quality of firms accepted in Tehran Stock Exchange. Applied Mathematics in Engineering, Management and Technology, 1(3), 58-63.

James, I. O., \& Izien, F. O. (2014). Audit Firm Characteristics and Audit Quality in Nigeria. International Journal of Business and Economics Research, 3(5), 187.

Jensen, M. C. (1993). The Modern Industrial Revolution, Exit, and the Failure of Internal Control Systems. Journal of Finance, 48(3), 831-880.

Kalezić, Z. (2015). Ownership concentration and firm performance in transition economies: Evidence from Montenegro. Journal of Central Banking Theory and Practice, 4(3), 5-64.

Karim, A. K. . W., van Zijl, T., \& Mollah, S. (2013). Impact of board ownership, CEO-Chair duality and foreign equity participation on auditor quality choice of IPO companies. International Journal of Accounting \& Information Management, 21(2), 148-169.

Kasim, N., Hashim, N. A. B., \& Salman, S. A. (2016). Conceptual Relationship between Corporate Governance and Audit Quality in Shari'ah Compliant Companies Listed on Bursa Malaysia. Modern Applied Science, 10(7), 106. 
Kaufmann, P. J., Gordon, R. M., \& Owers, J. E. (2000). Alternative profitability measures and marketing channel structure: The franchise decision. Journal of Business Research, 50(2), 217-224.

Khasharmeh, H., \& Joseph, N. (2017). Does ownership structure affects audit quality: Evidence from Bahrain? Global Journal of Accounting, Economics and Finance Full, 4(3), 92-100.

Kheirollahi, F., Behshour, I., \& Azadi, M. (2014). ( Company Ownership Structure ) on Audit Quality, 4(3), 465-469.

Knechel, W. R., \& Vanstraelen, A. (2007). The relationship between auditor tenure and audit quality implied by going concern opinions. Auditing, 26(1), 113-131.

Lazonick, W., \& O’Sullivan, M. (2000). Maximizing shareholder value : a new ideology for corporate governance Maximizing shareholder value : a new ideology for. Economy and Society, 29(1), 13-35.

Lin, J. W. (2010). Audit Quality, Corporate Governance, and Earnings ija_403 57..78 Management: A MetaAnalysis. International Journal of Auditing, 19(4), 187-191.

Liu, C. L., \& Lai, S. M. (2012). Organizational Complexity and Auditor Quality. Corporate Governance (Oxford), 20(4), 352368.

Liu, J., Wang, Y., \& Wu, L. (2011). The Effect of Guanxi on Audit Quality in China. Journal of Business Ethics, 103(4), 621-638.

Mahdavi, G., Maharlouie, M. M., Ebrahimi, F., \& Sarikhani, M. (2011). The Impact of Corporate Governance on Auditor Choice. International Research Journal of Finance and Economics Issue, 68(68).

Makni, I., Kolsi, M. C., \& Affes, H. (2012). The Impact of Corporate Governance Mechanisms On Earnings
Management: Evidence From Banks In Ethiopia. The IUP Jounal of Corporate Governance, XI(3), 48-70.

Md Noor, R., Mastuki, N., \& Badai, B. (2008). the Impact of Board Composition, Ownership and Ceo Duality on Audit Quality: the Malaysian Evidence. Malaysian Accounting Review, 7(2), 1-20.

Mgbame, C. O., Eragbhe, E., \& Osazuwa, N. P. (2012). Audit Partner Tenure and Audit Quality: An Empirical Analysis. European Journal of Business and Management, 4(7), 2222-2839.

Mohammed, A. M., Joshua, O., \& Nma Ahmed, M. (2018). Audit Fees and Audit Quality: A Study of Listed Companies in the Downstream Sector of Nigerian Petroleum Industry, (January).

Ndubuisi, A. N., \& Ezechukwu, B. O. (2017). Determinants of Audit Quality: Evidence from Deposit Money Banks Listed on Nigeria Stock Exchange. International Journal of Academic Research in Accounting, Finance and Management Sciences, 7(2), 117-130.

Niskanen, Karjalainen, \& Niskanen. (2009). Audit Firm Tenure and Audit Quality: Insights from Quantile Regression Audit Firm Tenure and Audit Quality: Insights from Quantile Regression, 1-34.

Niskanen, M., Karjalainen, J., \& Niskanen, J. (2011). Demand for Audit Quality in Private Firms: Evidence on, 65, 43-65.

https://doi.org/10.1111/j.10991123.2010.00422.x

Odudu, A. B. U. S., Terzungwe, N., \& Joshua, O. (2018). Institutional and Block-holder Ownership and Audit Quality of Listed Manufacturing Firms in Nigeria, 6(1), 15-26. https://doi.org/10.12691/jfa-6-1-3

Okpanachi, J. (2018). Audit Fees and Audit Quality: A Study of Listed Companies in the Downstream Sector 
of Nigerian Petroleum Industry Article. Research Gate, (September), 59-73.

https://doi.org/10.18488/journal.73.2

018.62 .59 .73

Olayinka. (2017a). Effect of Audit Fees on

Audit Quality: Evidence from Cement Manufacturing Companies in Nigeria. European Journal of Accounting, Auditing and Finance Research, 5(1), 6-17.

Olayinka, O. H. (2017b). Effect of Audit Fees on Audit Quality: Evidence from Cement Manufacturing Companies in Nigeria, 5(1), 6-17.

Oscar Mgbame, C., \& Eragbhe Nosakhare Peter Osazuwa, E. (2012). Audit Partner Tenure and Audit Quality: An Empirical Analysis. European Journal of Business and Management, 4(7), 2222-2839.

Palmrose, Z.-V. (1988). An Analysis of Auditor Litigation and Audit Service Quality. The Accounting Review, 63(1), 55-73.

Pham, N. K., Duong, H. N., Pham, T. Q., \& Ho, N. T. T. (2017). Audit Firm Size, Audit Fee, Audit Reputation and Audit Quality: The Case of Listed Companies in Vietnam. Asian Journal of Finance \& Accounting, 9(1), 429.

Pouraghajan, A., Ali, N., Tabari, Y., \& Haghparast, M. (2013). www.engineerspress.com The Effect of Ownership Structure on Audit Quality: Evidence from Tehran Stock Exchange.

Pratama, B., \& Muchamad, S. (2013). Pengaruh struktur kepemilikan perusahaan terhadap kualitas audit, 2, $1-13$.

Rahmina, L. Y., Agoes, S., Rohami, S., Wan Nordin, W. H., Mohd. 'Atef, M. Y., Md Hairi, M. H., ... IAASB. (2015). An empirical analysis of auditor independence and audit fees on audit quality. International Journal of Management and Business Studies, 3(3), 99-109.
Reed, B. J., Trombley, M. A., \& Dhaliwal, D. S. (2000). Demand for Audit Quality: The Case of Laventhol and Horwath' s Auditees. Journal of Accounting, Auditing \& Finance, 15(2), 183-198.

Rezaei, F., \& Shabani, S. (2014). Overview on Enhancing Audit Quality in the Public Interest: A Focus on Professional Skepticism, Quality Control and Group Audits. European Online Journal of Natural and Social Sciences, 3(1), 56-64.

Rinaldi, sony faisal, \& Mujianto, B. (2017). Metodologi-Penelitian-danStatistik-SC.

Rohami, S., Wan Nordin, W. H., Mohd. 'Atef, M. Y., \& Md Hairi, M. H. (2009). Audit Firm Tenure and Auditor Reporting Quality: Evidence in Malaysia. International Business Research, 2(2), 99-109.

Sajadi, S. ., Farazmand, H., \& Ghorbani, S. . (2012). The Effect of Auditor Tenure on Audit Quality. Journal of Accounting Advances (J.A.A), 4(4), 62-63.

Sakka, I. F., \& Jarboui, A. (2015). External auditor's characteristics, corporate governance and audit reporting quality. International Journal of Accounting and Economics Studies, 3(2), 109.

Salleh, Z., \& Manson, S. (2006). The impact of board composition and ethnicity on audit quality: Evidence from Malaysia companies. Malaysian Accounting Review, 5(2), 61-83.

Siregar, S. V., Amarullah, F., Wibowo, A., \& Anggraita, V. (2012). Audit tenure, auditor rotation, and audit quality: The case of Indonesia. Asian Journal of Business and Accounting, 5(1), $55-74$.

Soliman, M., \& Elsalam, M. (2013). Corporate Governance Practices and Audit Quality: An Empirical Study of the Listed Companies in Egypt. Ssrn, 6(11), 3101-3106. https://doi.org/10.2139/ssrn.2257815 
Soliman, M. M., \& Elsalam, M. A. (2012). Corporate Governance Practices and Audit Quality: An Empirical Study of the Listed Companies in Egypt. World Academy of Science, Engineering and Technology, 12921297.

Sugiyono. (2017). Metode Penelitian Kuantitatif, Kualitatif, dan R\&D. Bandung.

Sumantaningrum, Y. L., \& Kiswara, E. (2017). Pengaruh struktur kepemilikan terhadap kualitas audit dengan variabel moderasi imbalan audit, $6,1-13$.

Talebnia, G., Baghiyan, F., \& Baghiyan, Z. (2017). The Impact of Corporate Governance Mechanisms on Audit Quality Email address :, 5(2005), 8791.

Varici, I. (2013). The Relationship between Information Asymmetry and the Quality of Audit: An Empirical Study in Istanbul Stock Exchange. International Business Research, 6(10), 132-140.

Velnampy, T., Sivathaasan, N., Tharanika, R., \& Sinthuja, M. (2014). Board Leadership Structure, Audit Committee and Audit Quality: Evidence from Manufacturing Companies in Sri Lanka. International Journal of Business and Management, 9(4), 76-85.

Veronica, S., \& Anggraita, V. (2016). Impact of Abnormal Audit Fee to Audit Quality: Indonesian Case Study, 6(1), 72-78.

Wan Abdullah, W. Z., Shahnaz, I., \& Nurasyikin, J. (2008). The impact of board composition, ownership and CEO duality on audit quality: The Malaysian evidence. Malaysian Accounting Review, 7(2), 17-29.

Wang, L., \& Zhu, L. (2018). State Ownership , Auditor Rotation and Audit Quality, 205(Iccese), 11691173.

Yasin, F. M., \& Nelson, S. P. (2013). Audit Committee and Internal Audit:
Implications on Audit Quality. International Journal of Economics, Management and Accounting International Journal of Economics Management and Accounting, 20(122), 187-218.

Zureigat, Q. (2011). The Effect of Ownership Structure on Audit Quality: Evidence from Jordan. International Journal of Business and Social Science, 2(10), 38-46. 